\title{
Grazing pressure by amphipods on microalgae in Gamo Lagoon, Japan
}

\author{
Samuel Aikins*, Eisuke Kikuchi \\ Center for Northeast Asian Studies, Tohoku University, Sendai 980-8576, Japan
}

\begin{abstract}
Grazing effects of amphipods were examined for 3 groups of diatoms (loosely attached cells, moderately attached cells and strongly attached cells) in Gamo Lagoon, Miyagi Prefecture, Japan. Diatom species with filamentous forms or low adhesive strength were susceptible to grazing, while those with stronger adhesion were less affected by grazing pressure. Seasonal trends for both amphipods and microalgae found on the macroalgae Gracilaria vermiculophylla showed high densities of amphipods and low densities of microalgae during warmer months (June to September) and vice versa in colder months (December to March). This inverse relationship between densities of amphipods and diatoms suggests a causal relationship and that effects of grazing pressure by amphipods on epiphytic diatom communities seem to be strong in Gamo Lagoon. A manipulative experiment (feeding pressure experiment) revealed that Melosira sp. and Nitzschia sp. were mostly selected by tube-dwelling species (Corophium uenoi and Grandidierella japonica), whilst Gyrosigma sp. and Melosira sp. were mostly selected by free-living species (Eogammarus possjeticus and Melita setiflagella).
\end{abstract}

KEY WORDS: Grazing pressure $\cdot$ Amphipods $\cdot$ Diatom $\cdot$ Algae $\cdot$ Gamo Lagoon

Resale or republication not permitted without written consent of the publisher

\section{INTRODUCTION}

The presence of epiphytes on aquatic macrophytes has been noted in communities worldwide, but their role has often been difficult to assess. In aquatic environments, epiphytes have been found to contribute to the primary productivity of the ecosystem (Brock 1970, Finke 1978, Jones 1980) and also supply food for grazers (Randall 1964, Reyes-Vasquez 1970, Berg 1974, Zimmermann et al. 1979, Morgan 1980, Brawley \& Adey 1981). Therefore epiphytes are important components of food webs in an aquatic ecosystem.

Grazing pressure of epifauna on periphyton has been reported by D'Antonio (1985) to cause significant periphyton biomass reductions. Previous studies by Zimmerman et al. (1979) revealed the capacity of amphipods to reduce periphyton biomass. Admiraal (1977) reported that the benthic microflora contributes considerably to the primary production in the Ems-

*Email: aikins@mail.cc.tohoku.ac.jp
Dollard estuary and consists largely of diatoms. Many laboratory and field experiments have shown that the standing crop and species composition of benthic diatoms are influenced by grazing pressure (Hickman \& Round 1970, Nicotri 1977, Kawamura \& Hirano 1992). Reduction of microalgae biomass on macroalgae has been observed in Gamo Lagoon, especially during summer. Considering the important position of microalgae in the aquatic food chain, studies of prey choice among estuarine omnivores feeding on epiphytic microalgae are very necessary. For the epibenthic diatom community, grazing pressure can have a determinant effect on species composition and diversity (Sumner \& Mclntire 1982), biomass (Castenholz 1961, Calow 1973) and vertical development (Nicotri 1977, Kesler 1981). In Gamo Lagoon, grazing pressure exerted by amphipods on microalgae was investigated after observation of an increase in attached material during the winter months that disappears in summer. The aim of this work is to elucidate some of the factors causing this seasonal variation in attached material. 
Many amphipods are known to assimilate microscopic flora (bacteria, fungi and diatoms) more efficiently than the organic substratum on which they grow (detritus, macroalgae and vascular plants) (Zimmerman et al. 1979, Morrison \& White 1980). In the present investigation, we examined the role of the strength of adhesion of microalgae to surfaces in their susceptibility to grazing by amphipods. Grazing effects were examined for 3 groups of diatoms: loosely, moderately and strongly attached cells. In order to examine the grazing effects of amphipods on microalgae, seasonal trends of both amphipods and microalgae were determined. To obtain a detailed picture of the relationship between amphipods and microalgae, a manipulative experiment was carried out in Gamo Lagoon to assess the feeding preferences of several amphipod species.

\section{MATERIALS AND METHODS}

Study site and sampling of macroalgae. Field investigations and experiments were carried out in the estuarine environment of Gamo Lagoon (Fig. 1), a small brackish lagoon at the mouth of the Nanakita River running through the northern part of Sendai City, NE Japan $\left(38^{\circ} 15^{\prime} \mathrm{N}, 141^{\circ} 00^{\prime} \mathrm{E}\right)$, that covers a total area of about 10 ha. A stone levee with 3 rectangular entry channels forms a gateway through which lagoon water is exchanged via tidal movement. Salinity varies from 5 to $30 \%$ at the center of Gamo Lagoon according to tidal state (Kurihara et al. 1997). Average daily water temperatures were maximum during July and August $\left(25\right.$ and $\left.30^{\circ} \mathrm{C}\right)$, and minimum during January and February (3 and $6^{\circ} \mathrm{C}$ ) (Kurihara et al. 1997). During low tides, sandy mud flats appear in the outer and central parts of the lagoon and outside the levee, whereas the innermost part of the lagoon remains covered by water (Kikuchi et al. 1980).

Samples of the macroalga Gracilaria vermiculophylla (Ohmi) Papenfuss were collected monthly from 2 stations (Stn 1 and Stn 2; Fig. 1) located approximately 200 and $800 \mathrm{~m}$ from the levee of Gamo Lagoon, respectively. Stn 1 was located in a backwater of the lagoon near the seaward end, and Stn 2 in the innermost reaches of the lagoon. G. vermiculophylla was found at both stations. Monthly samples were taken from January to December 1999 using a $0.25 \mathrm{~m}^{2}$ quadrat placed randomly at algal sites at both stations. Four replicates were sampled at both stations per visit on the same day per month. G. vermiculophylla was gently pulled from the sediment by hand and placed in polyethylene bags. Chilled samples (in icebox filled with ice blocks) were then transported to the laboratory for further treatment.
In the laboratory, attached materials were scraped from the macroalgae. Identification and cell counts of sub-sampled diatoms fixed in $2.5 \%$ glutaraldehyde solution were done under a light microscope. For each replicate, 6 sub-samples of $0.1 \mathrm{ml}$ were further sampled for counting. Algal samples were treated in 3 ways to remove all attached material: (1) loosely attached material was rinsed off each sample with $200 \mathrm{ml}$ distilled water into a plastic tray; (2) moderately attached material was washed vigorously from each sample with $200 \mathrm{ml}$ distilled water into a second tray; (3) strongly attached material was removed completely from thalli with a nail brush and placed into a third tray. The algal samples were drained for ca. $30 \mathrm{~min}$ and oven-dried for $48 \mathrm{~h}$; dry weight was then determined to the nearest $0.05 \mathrm{~g}$.

Macrofauna were identified to species under a stereoscopic microscope. Each species was stored in a separate sampling bottle containing $70 \%$ ethanol and counted to determine density. Chlorophyll $a$ and $C$ contents were determined for all 3 groups of attached material from the macroalgae by the acetone extraction method of Lorenzen (1967).

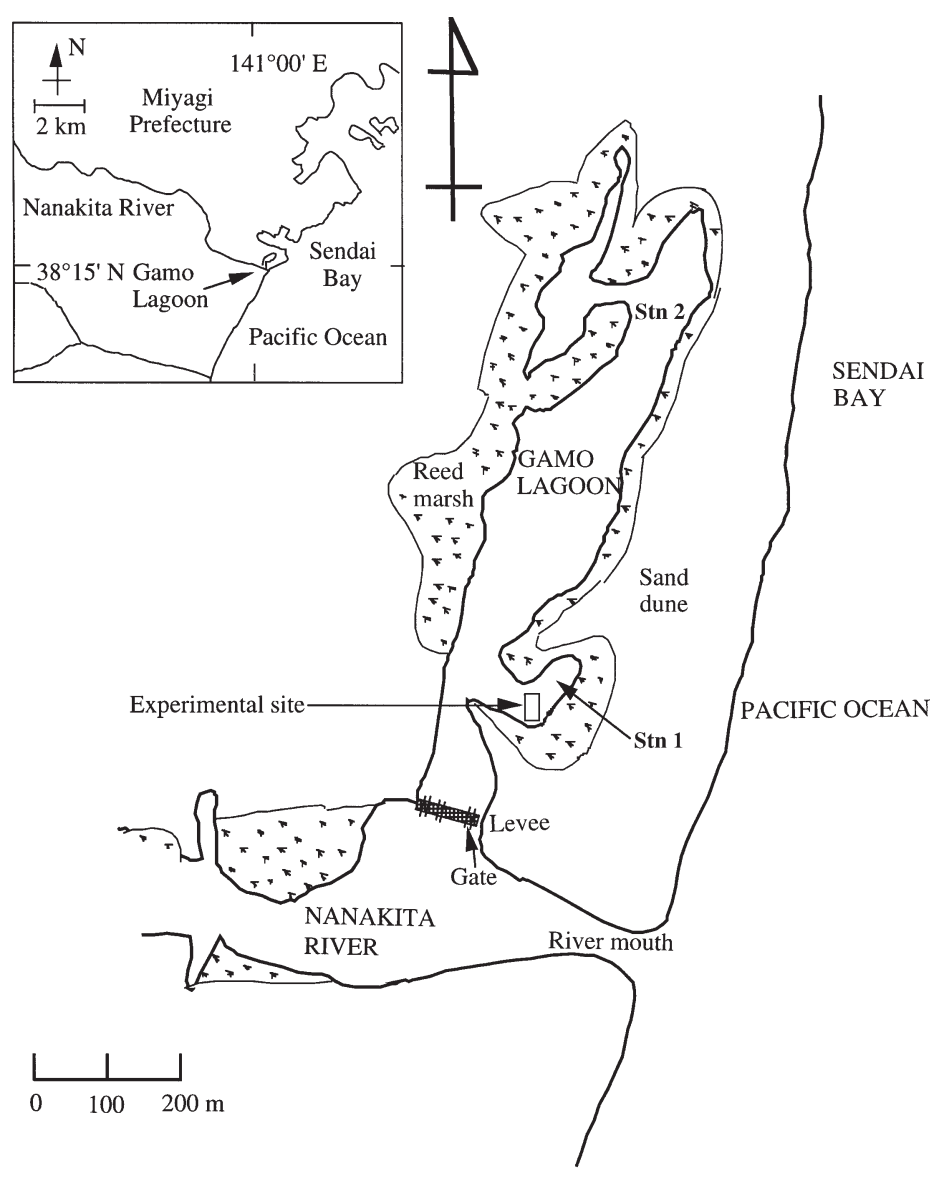

Fig. 1. Study sites in Gamo Lagoon, Japan 

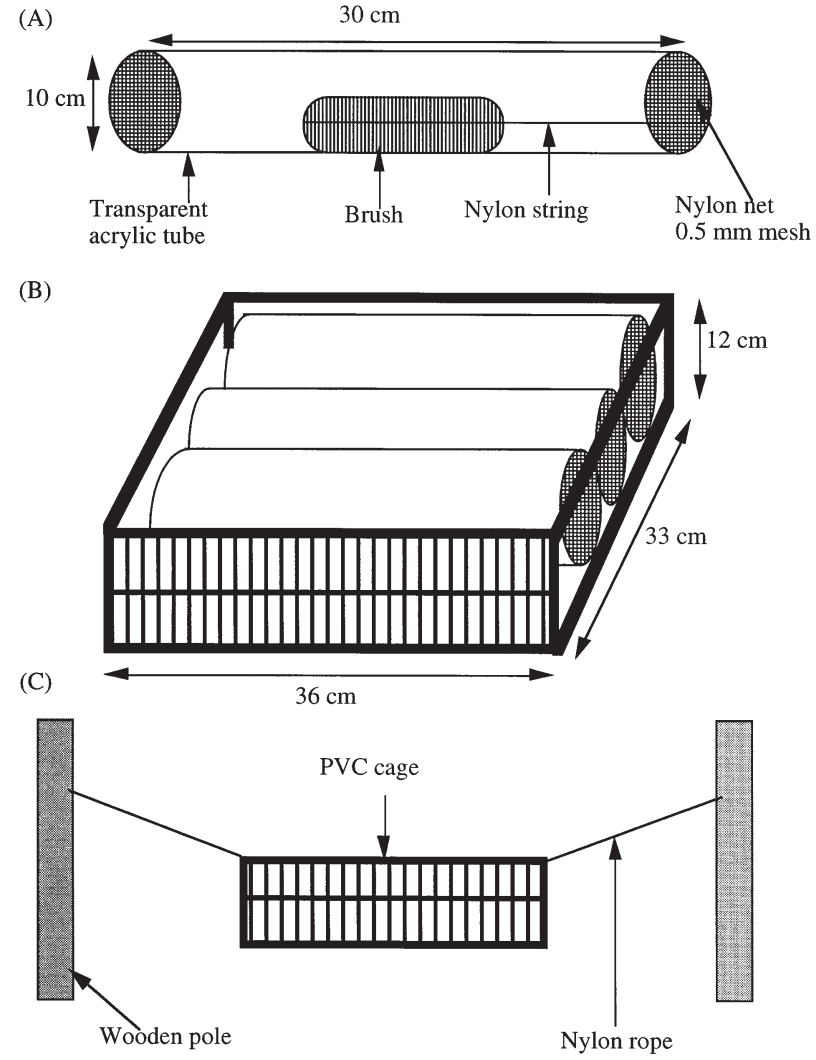

Fig. 2. Experimental design and setup in Gamo Lagoon. (A) Acrylic tube with inserted brush; (B) PVC cage with 3 tubes; (C) PVC cage setup

Feeding pressure experiment. A manipulative experiment was set up in August 2000 inside the lagoon approximately $200 \mathrm{~m}$ from the levee, near Stn 1 (Fig. 1), and was sampled after 2 wk. For the feeding pressure experiment, we used 4 species of amphipods (Corophium uenoi, Eogammarus possjeticus, Melita setiflagella and Grandidierella japonica) from Gamo Lagoon. These species are dominant and widely distributed on natural and artificial substrates in Gamo Lagoon (Aikins \& Kikuchi 2001). Cultures of 50 adults of each species were inoculated into separate tubes of almost $0.25 \mathrm{~m}^{2}$, corresponding to the minimum density of M. setiflagella (198 ind. $\mathrm{m}^{-2}$ ) in August in the field.

For the experimental set up, one end of a transparent acrylic tube (30 cm length, $10 \mathrm{~cm}$ diameter) was sealed with a nylon plankton net $(0.5 \mathrm{~mm}$ mesh) (Fig. 2). Brushes were used as a substrate substitute for natural algae, since they support a diatom species composition similar to that of Gracilaria vermiculophylla (see Table 2). The brushes were made of polypropylene strings and were cylindrical in shape (10.5 cm length, $5.0 \mathrm{~cm}$ diameter); their filamentous nature is similar to that of natural substrate (macro- algae), and they provide a suitable habitat for the amphipods (Aikins \& Kikuchi 2001). Brush substrates were inserted into tubes by nylon strings, the various amphipod species were inoculated into the tubes and the open end was sealed with nylon plankton net (0.5 mm mesh).

Three sealed transparent acrylic tubes, each containing different amphipod species, were placed together in a PVC (polyvinyl chloride) cage $(36 \times 33 \times$ $12 \mathrm{~cm})$. The cages were suspended in the lagoon water on nylon ropes (Fig. 2). Control tubes (without amphipods) were placed randomly among inoculated tubes. Five replicates of each amphipod species in tubes and 7 control tubes were set and sampled $2 \mathrm{wk}$ later. In all, 9 PVC cages containing a total of 27 tubes were set up.

Samples were transported on ice to the laboratory for further treatment. Attached materials removed from brush substrates were fixed in $2.5 \%$ glutaraldehyde solution for identification, cell counts and species composition. TWINSPAN (Hill 1979, Jongman et al. 1987) was carried out using PC-ORD for Windows (Version 3.2.0). Cluster analysis (single linkage method) was used to reveal the similarities in diatom selection by the 4 species of amphipods.

\section{RESULTS}

\section{Monthly changes in Gracilaria vermiculophylla biomass and amphipods}

Maximum and minimum dry biomasses $\left(\mathrm{g} \mathrm{m}^{-2}\right)$ of Gracilaria vermiculophylla at Stns 1 and 2 were recorded in the warmer (June to September) and colder (December to March) months, respectively (Fig. 3). At Stn 1, dry biomass increased from March, reached a peak of about $600 \mathrm{~g} \mathrm{~m}^{-2}$ in July, and declined steadily to a minimum of $120 \mathrm{~g} \mathrm{~m}^{-2}$ in February. A similar trend occurred at Stn 2: dry biomasses of 810 and $75 \mathrm{~g} \mathrm{~m}^{-2}$ were recorded in July and February, respectively.

For all species of amphipods, high and low densities were found in the warmer and colder months, respectively (Fig. 4). The amphipods have 2 kinds of lifestyles: the tube-dwelling species Corophium uenoi and Grandidierella japonica construct and live in tubes; the free-living species Eogammarus possjeticus and Melita setiflagella cling to or crawl over algae without constructing tubes (Table 1). There was a clear positive correlation between tube-dwellers and macroalgal biomass at both stations: correlation at Stns 1 and 2 was significant at the 5 and $1 \%$ levels, respectively (Table 1). Of the free-living species, $M$. setiflagella showed a positive correlation $(\mathrm{p}<0.01)$ at Stn 1 , 


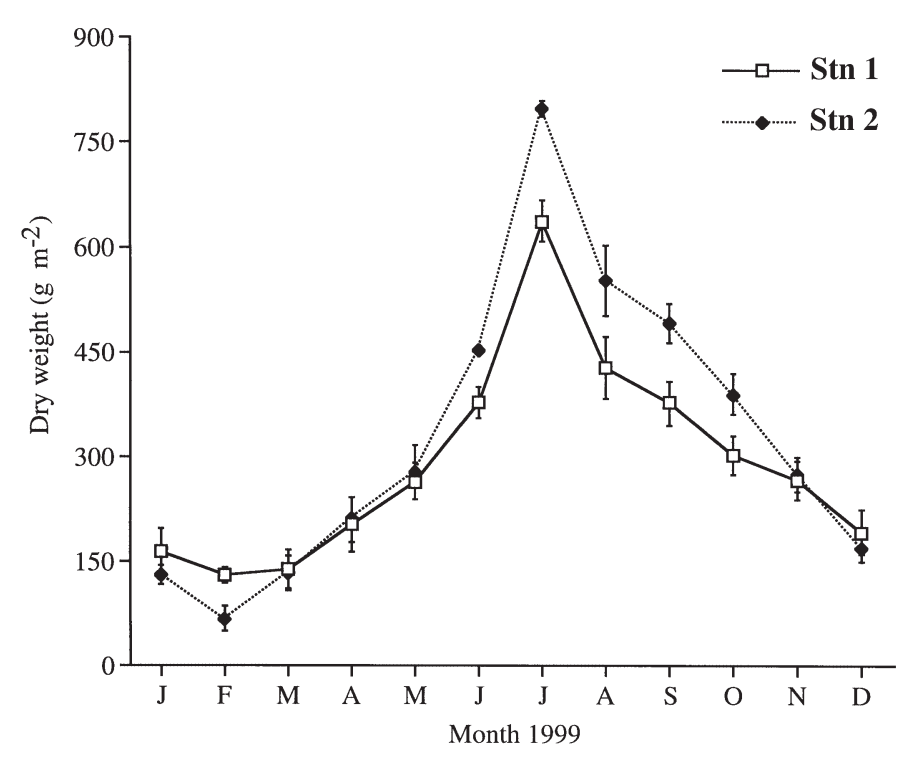

Fig. 3. Gracilaria vermiculophylla. Monthly changes in biomass (dry wt, $\mathrm{g} \mathrm{m}^{-2}$ ) at Stns 1 and 2 in Gamo Lagoon. Bars indicate $\mathrm{SD}, \mathrm{n}=4$

while E. possjeticus did not show any significant correlation with macroalgal biomass at either station. This suggests that tube-dwelling species are dependent on algal biomass whilst free-living species have only a partial dependency.

\section{Total attached material (microalgae and detritus) on Gracilaria vermiculophylla}

Both stations had maximum attached material loads of 1.5 and $3.5 \mathrm{~g} \mathrm{~g}^{-1}$ in February with a minimum of $0.2 \mathrm{~g} \mathrm{~g} \mathrm{~g}^{-1}$ in September and July for Stns 1 and 2, respectively (Fig. 5). Between April and November, $<1.0 \mathrm{~g} \mathrm{~g}^{-1} \mathrm{mo}^{-1}$ was recorded at both stations. Attached material began increasing after November and attained a peak in February. There were more attached materials at Stn 2 than at Stn 1.

Table 1. Relationship between densities of 4 amphipod species and dry algal biomass at Stns 1 and 2 in Gamo Lagoon, Japan. Values are correlation coefficient (r). ${ }^{*} \mathrm{p}<0.05,{ }^{* *} \mathrm{p}<0.01$

\begin{tabular}{|lcc|}
\hline Amphipod species & $\operatorname{Stn} 1(\mathrm{n}=30)$ & $\operatorname{Stn} 2(\mathrm{n}=30)$ \\
\hline Tube-dwellers: & & \\
$\quad$ Corophium uenoi & $0.566^{*}$ & $0.682^{* *}$ \\
Grandidierella japonica & $0.599^{*}$ & $0.683^{* *}$ \\
Free-living: & & \\
Eogammarus possjecticus & 0.474 & 0.525 \\
Melita setiflagella & $0.534^{*}$ & 0.521 \\
\hline
\end{tabular}

\section{Density of 3 groups of diatom cells on Gracilaria vermiculophylla}

High densities of diatom cells (nos. $\mathrm{g}^{-1}$ ) were found during the colder months, while low densities occurred during warmer months at both stations. Considering the total number of diatom cells irrespective of these categories, more diatom cells were found at Stn 1 than at Stn 2 (Fig. 6).

At Stn 1, as many as $275 \times 10^{3}$ strongly attached cells $\mathrm{g}^{-1}$ macroalga were recorded in February 1999. Densities of diatom cells declined after March through April and were lowest in June. Fairly constant densities were recorded from June until September, and these began to increase after October for all groups of diatoms.

At Stn 2, a maximum density of about $200 \times 10^{3}$ moderately attached cells $\mathrm{g}^{-1}$ was recorded in February. As at Stn 1, densities of diatom cells declined after March, reaching a minimum in July and beginning to increase again after October. With respect to the 3 attachment categories, moderately attached cells recorded maximum and strongly attached cells displayed minimum densities at most times during the entire sampling period. Density of all diatom groups decreased in the warmer season, while that of amphipods increased during the same period.

\section{Monthly changes in chlorophyll $a$ and $c$ concentrations of attached material}

Both Stns 1 and 2 had higher concentrations of chlorophyll $c$ than chlorophyll a (Fig. 7). At Stn 1, moderately and strongly attached materials had higher concentrations of chlorophyll $a$ and $c$ than loosely attached materials.

At Stn 2, loosely attached materials had high concentrations of chlorophyll $a$ and $c$ compared to moderately and strongly attached materials. High and low concentrations of chlorophyll $a$ and $c$ were recorded in colder and warmer months, respectively, at both stations for all treatments.

\section{Monthly variations in diatom species on Gracilaria vermiculophylla}

Most diatom species had maximum and minimum densities in the colder and warmer months, respectively (Fig. 8). Nine diatom species (Gyrosigma sp., Nitzschia sp., Navicula sp., Melosira sp., Synedra sp., Triblionella sp., Surirella sp., Amphora sp. and Amphiprora sp.) were found on Gracilaria vermiculophylla at both stations, with Navicula sp., Melosira sp. 


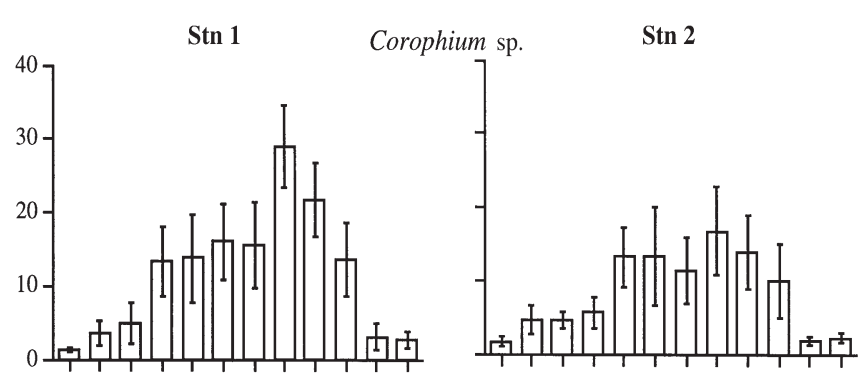

Eogammarus sp.

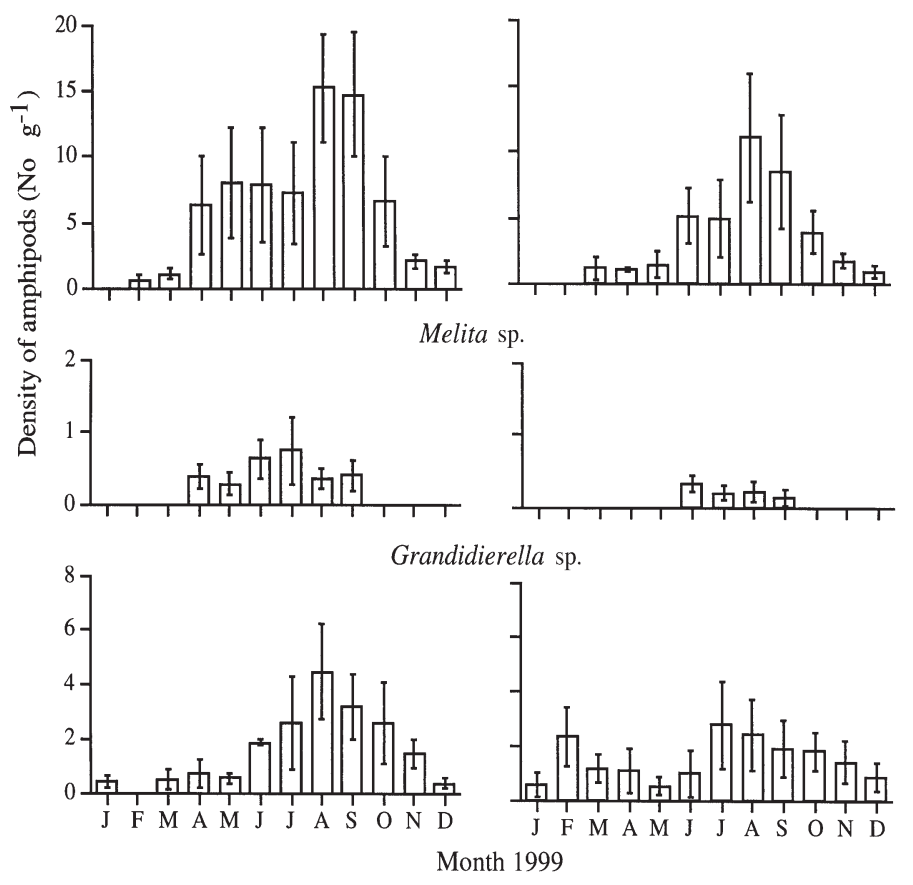

Fig. 4. Gracilaria vermiculophylla. Monthly changes in amphipod densities per gram algal biomass at Stns 1 and 2 in Gamo Lagoon. Bars indicate $\mathrm{SD}, \mathrm{n}=4$

and Synedra sp. occurring in especially high densities. High densities of Synedra sp. occurred in strongly attached material. Navicula sp. tend to be dominant in warmer months.

\section{Feeding-pressure experiment}

Eight diatom species (Navicula sp., Nitzschia sp., Gyrosigma sp., Melosira sp., Synedra sp., Triblinella sp., Surirella sp., and Amphora sp.) were found on the brush substrate used for the feeding pressure experiment (Fig. 9). An analysis of the similarities between the selection of diatoms revealed 2 primary clusters (Fig. 10). Tubes inoculated with amphipod species formed one cluster (CL 1), tubes without amphipods (control) formed another cluster (CL 2). CL 1 was further divided into 2 subgroups: CL 1-1 with tubes

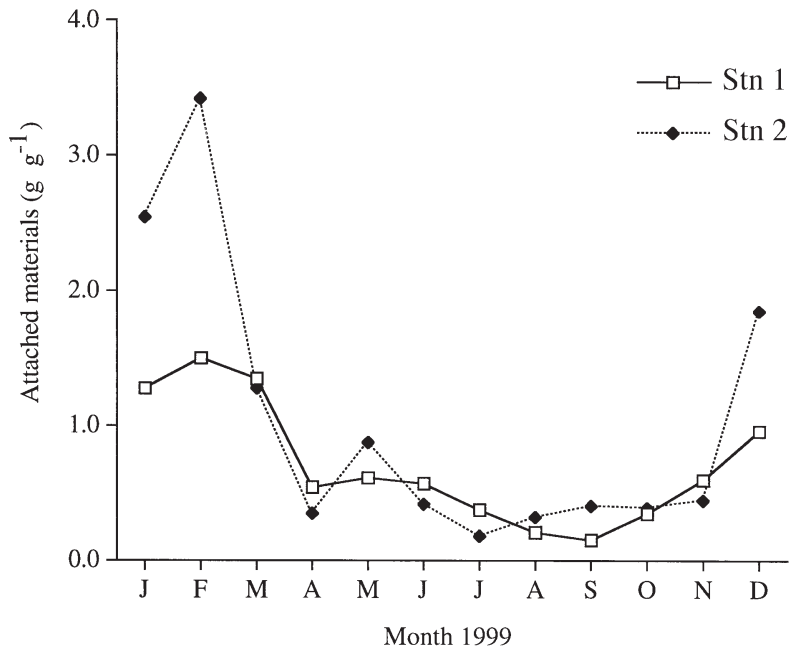

Fig. 5. Gracilaria vermiculophylla. Total attached material (incuding microalgae and detritus) per gram algal biomass at Stns 1 and 2 in Gamo Lagoon. Bars indicate SD, n = 4

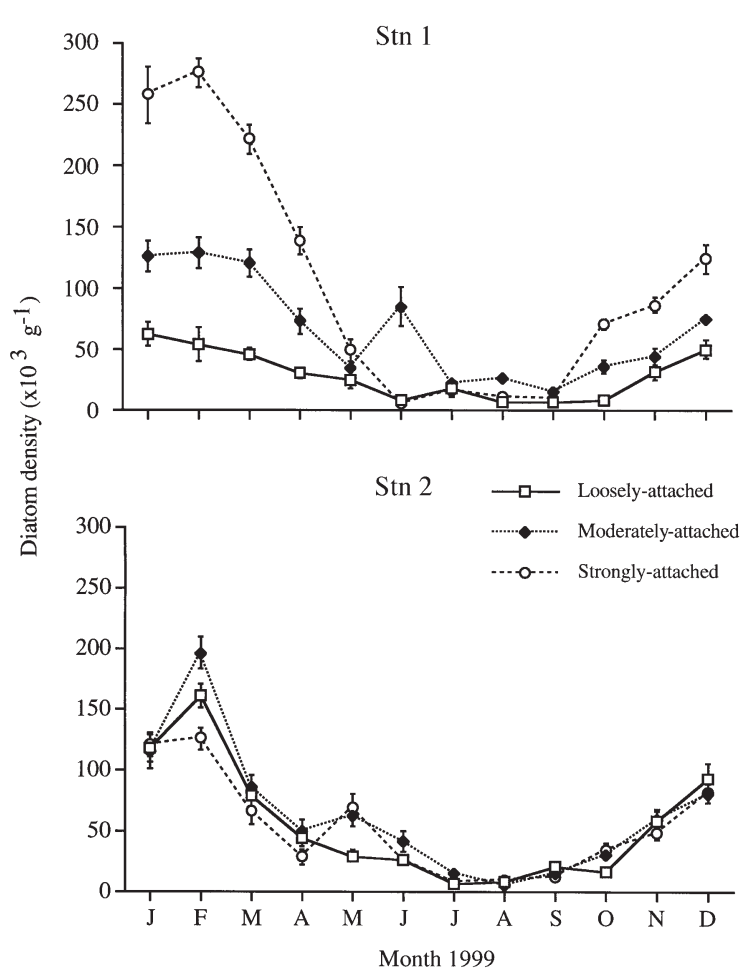

Fig. 6. Gracilaria vermiculophylla. Density of diatom cells per gram algal biomass $\left(\times 10^{3} \mathrm{~g}^{-1}\right)$ in Gamo Lagoon at Stns 1 and 2 . Grazing effects for 3 groups of diatoms (loosely, moderately and strongly attached cells). Bars indicate $\mathrm{SD}, \mathrm{n}=4$

inoculated with Eogammarus possjeticus and Melita setiflagella (free-living species); CL 1-2 with tubes inoculated with Corophium uenoi and Grandidierella japonica (tube-dwelling species) (Fig. 10). The diatom species composition on Gracilaria vermiculophylla in 


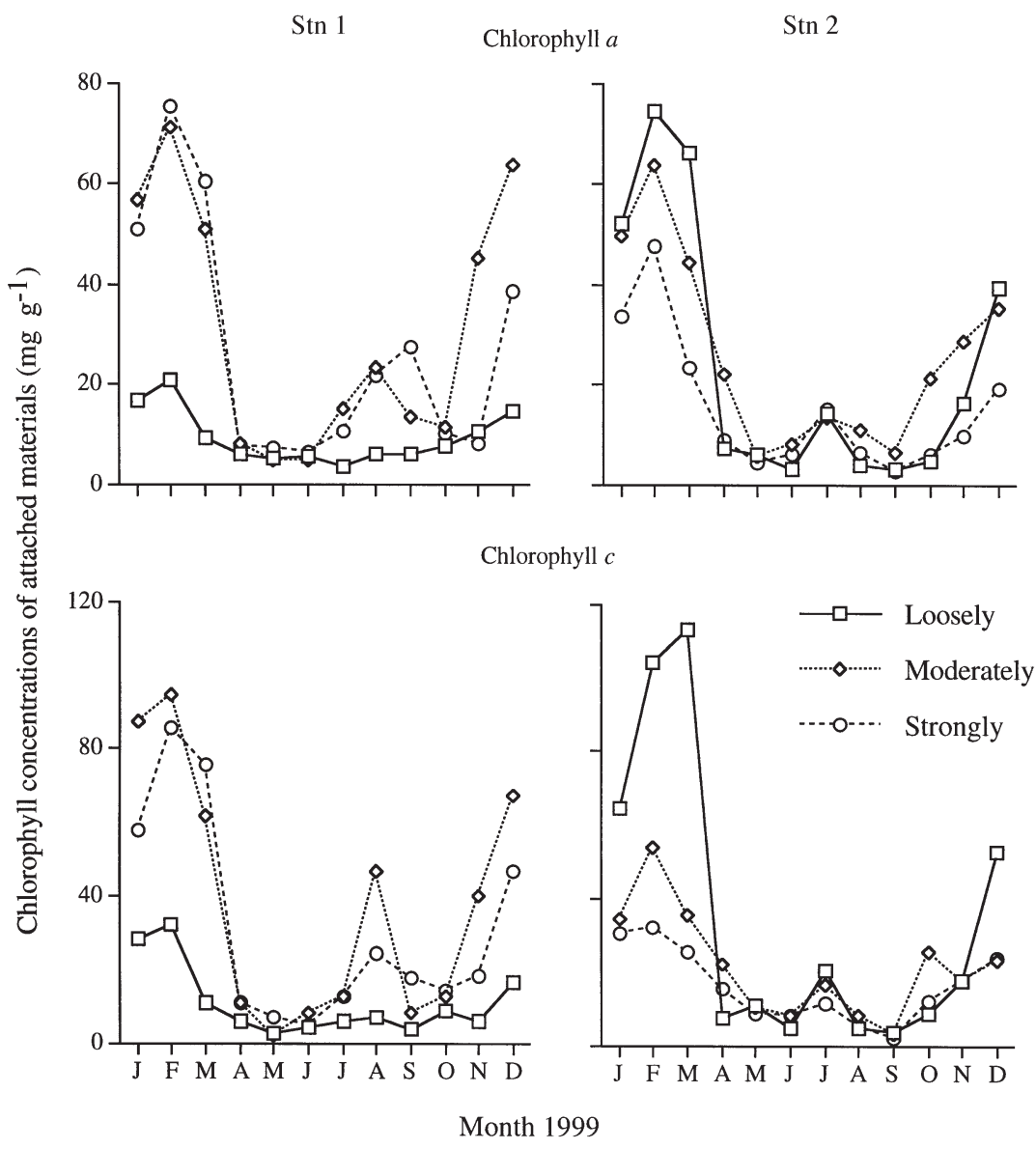

Fig. 7. Gracilaria vermiculophylla. Concentrations of chl $a$ and $c$ of attached materials per gram algal biomass $\left(\mathrm{mg} \mathrm{g}^{-1}\right.$ ) in Gamo Lagoon at Stns 1 and 2 from January to December 1999

February (Table 2) was similar to that on the brushes within control tubes. Eight diatom species appeared on the brush substrate in control tubes, but were less dense within inoculated tubes. In inoculated tubes, Melosira sp. were not found (Student's $t$-test, $\mathrm{p}<0.001$ ) (Fig. 9). As for G. japonica tubes, Nitzschia sp. and Melosira sp. were absent from tubes inoculated with Corophium uenoi. Low densities of Navicula sp., Gyrosigma sp., Synedra sp. and Triblinella sp. were recorded in C. uenoi and G. japonica tubes. Surirella sp. showed no significant change within $C$. uenoi and G. japonica tubes, whilst the decrease in densities of Amphora sp. was significant. Very few Gyrosigma sp., Melosira sp. and Surirella sp. were found in E. possjeticus tubes, and M. setiflagella tubes had low densities of Gyrosigma sp., Melosira sp. and Synedra sp. The effects of $C$. uenoi and $G$. japonica on diatoms were similar, whilst the effects of E. possjeticus and $M$. setiflagella on diatoms were also similar (Fig. 10). On the whole, all species of diatoms decreased in all tubes containing amphipods.

\section{DISCUSSION}

Grazing pressure effects have been reported to influence diatom densities (Hickman \& Round 1970, Kawamura \& Hirano 1992). The effect of grazing on epiphytic diatom communities seems to be strong in Gamo Lagoon. Our results revealed that diatom densities were highest in winter when amphipod densities were lowest, suggesting that amphipod grazing may have suppressed the diatoms when they might otherwise have been expected to be most abundant.

Two types of feeding, representing high and low feeding pressure, were observed in Gamo Lagoon. A rapid increase in the density of amphipods (Fig. 4) during spring resulted in a corresponding decrease in diatoms (Fig. 8), signifying a higher feeding pressure at this time. However, the inverse relationship that occurred in the colder months could have been due to low densities of invertebrates and/or low water temperature effects on their digestive efficiency, or slower physiological activities, which would result in lower feeding pressure.

Although amphipods are not the only invertebrates in Gamo Lagoon, they are known to be important grazers of diatoms and to have a great impact. According to Moore (1975), diatoms form a regular and relatively important part of the diet of Gammarus pulex living among Cladophora glomerata in Wellow Brook, England. In the present study high chlorophyll $a$ and $c$ concentrations of attached material (Fig. 7) indicate the presence of diatoms. The similar trends of seasonal changes in attached material

Table 2. Gracilaria vermiculophylla. Density of diatoms as a function of algal biomass (nos. $\mathrm{g}^{-1}$ ) and brush substrates $\left(\times 10^{2}\right.$ cell brush $\left.^{-1}\right)$ in Gamo Lagoon in February and August 2000. Values are mean $\pm 1 \mathrm{SD}, \mathrm{n}=4$

\begin{tabular}{|lccc|}
\hline \multirow{2}{*}{ Diatoms } & \multicolumn{2}{c}{ Macroalgae } & \multirow{2}{*}{ Brush } \\
& February & August & August \\
\hline Melosira sp. & $9652 \pm 543.6$ & $151 \pm 12.5$ & $644 \pm 105.3$ \\
Synedra sp. & $7617 \pm 367.4$ & $210 \pm 10.4$ & $642 \pm 97.8$ \\
Navicula sp. & $6709 \pm 346.2$ & $454 \pm 53.6$ & $1683 \pm 231.5$ \\
Nitzschia sp. & $1743 \pm 167.9$ & $278 \pm 31.4$ & $484 \pm 44.9$ \\
Triblinella sp. & $1458 \pm 211.9$ & $44 \pm 3.8$ & $407 \pm 59.5$ \\
Gyrosigma sp. & $1024 \pm 203.8$ & $28 \pm 4.6$ & $561 \pm 16.3$ \\
Amphora sp. & $597 \pm 45.7$ & $26 \pm 4.6$ & $486 \pm 66.7$ \\
Surirella sp. & $362 \pm 43.6$ & $28 \pm 5.9$ & $328 \pm 41.1$ \\
Amphiprora sp. & $43 \pm 6.8$ & $4 \pm 1.7$ & Not found \\
\hline
\end{tabular}




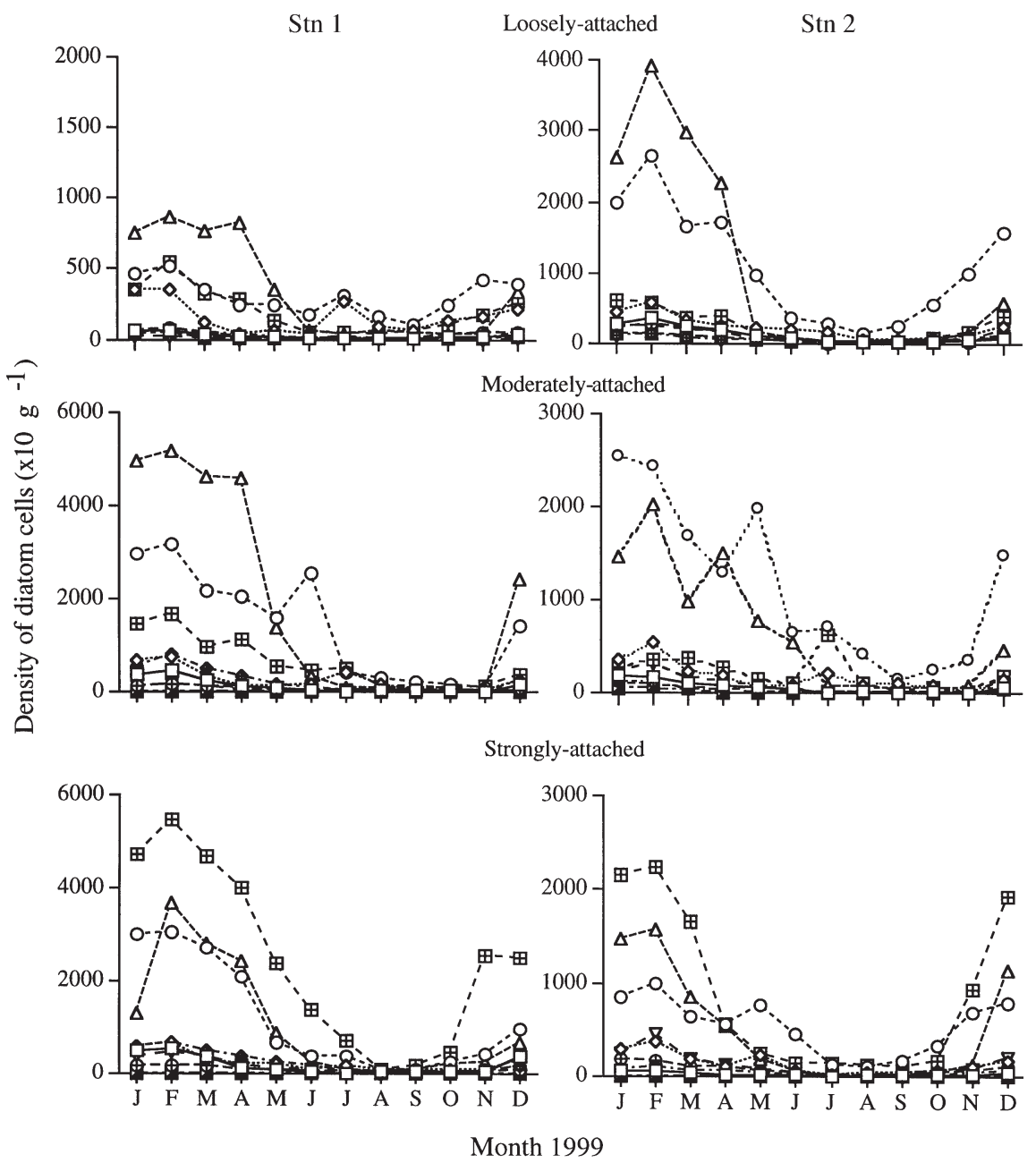

Fig. 8. Monthly density of diatom cells on Gracilaria vermiculophylla in Gamo Lagoon at Stns 1 and 2. $\square$ : Gyrosigma sp.; $\diamond:$ Nitzschia sp.; O: Navicula sp.; $\triangle$ : Melosira sp.; 田: Synedra sp.; $₫$ : Triblionella sp.; $\oplus:$ Suriella sp.; $\boldsymbol{\nabla}$ : Amphora sp.; 口: Amphiprora sp.

(Fig. 5) to those in concentrations of chlorophyll $a$ and $C$ suggest that diatoms contributed to changes in the attached material. The results of experiments in Gamo Lagoon also indicated that amphipods selected and fed on diatoms (Fig. 9). The disappearance of some diatom species from amphipod-inoculated tubes and their occurrence in control tubes suggests grazing of diatoms by amphipods in the experimental tubes (Fig. 10). Even though the density of the diatoms in the tubes might depend on their growth rate, any density difference between control and inoculated tubes would be a result of amphipod feeding, since diatom growth rate would not differ. The use of a brush substrate as a substitute of Gracilaria vermiculophylla was validated by the similarity in species composition (Table 2) on both substrates. Brush substrates provided exact replicates of conditioned substrates.
In general, species of filamentous form or with low adhesive strength are apt to be more heavily grazed, while species with stronger adhesion are less affected by grazing pressure (Moore 1975, Nicotri 1977, Hudon 1983, Suzuki et al. 1987, Steinman et al. 1989). Moore (1975) reported that Melosira varians and Diatoma vulgare, diatoms forming long filamentous colonies, were ingested in disproportionately large quantities by amphipods, whereas Cocconeis sp., a highly adhesive prostrate forms, was rarely eaten. The results of our feeding-pressure experiment in Gamo Lagoon showed that all amphipod species selected Melosira sp. (Fig. 9), a colony enclosed in a filamentous, arborescent, mucous tube, emphasizing the importance of diatom morphology in amphipod feeding. In general, larger varieties of grazers prefer arborescent and filamentous colonial diatoms over small, prostrate forms (Hudon 1983). Similarly, Synedra sp., which is a non-motile, fanshaped colony standing upright on macroalgae, occurred in higher densities among strongly attached cells (Fig. 8). This may be partially due to its mode of attachment, but the experimental results suggest that this species was ingested fairly efficiently by the amphipods (Fig. 9).

Our results show that almost all diatom species found were ingested by the amphipods (Fig. 9). However, total ingestion of Melosira sp. and Nitzschia sp. was recorded for the tube-dwelling amphipods Corophium uenoi and Grandidierella japonica, whilst total ingestion of Gyrosigma sp. and Melosira sp. were common to the free-living species Eogammarus possjeticus and Melita setiflagella (Student's $t$-test, $\mathrm{p}<0.001$ ). Surirella sp. seems to be ingested mainly by free-living species and not by tube-dwellers. Diatom selection, therefore, was similar among free-living amphipods and similar among tube-dwellers, but it differed between the 2 groups (Fig. 10). This suggests that life form and lifestyle of diatoms influence the degree of grazing effect exerted by amphipods.

Hudon (1983) reported that larger diatoms were not selected by the amphipod Calliopius laeviusculus. Smaller and medium-sized diatoms may be preferred over larger cell diatoms. However a larger diatom, Gy- 


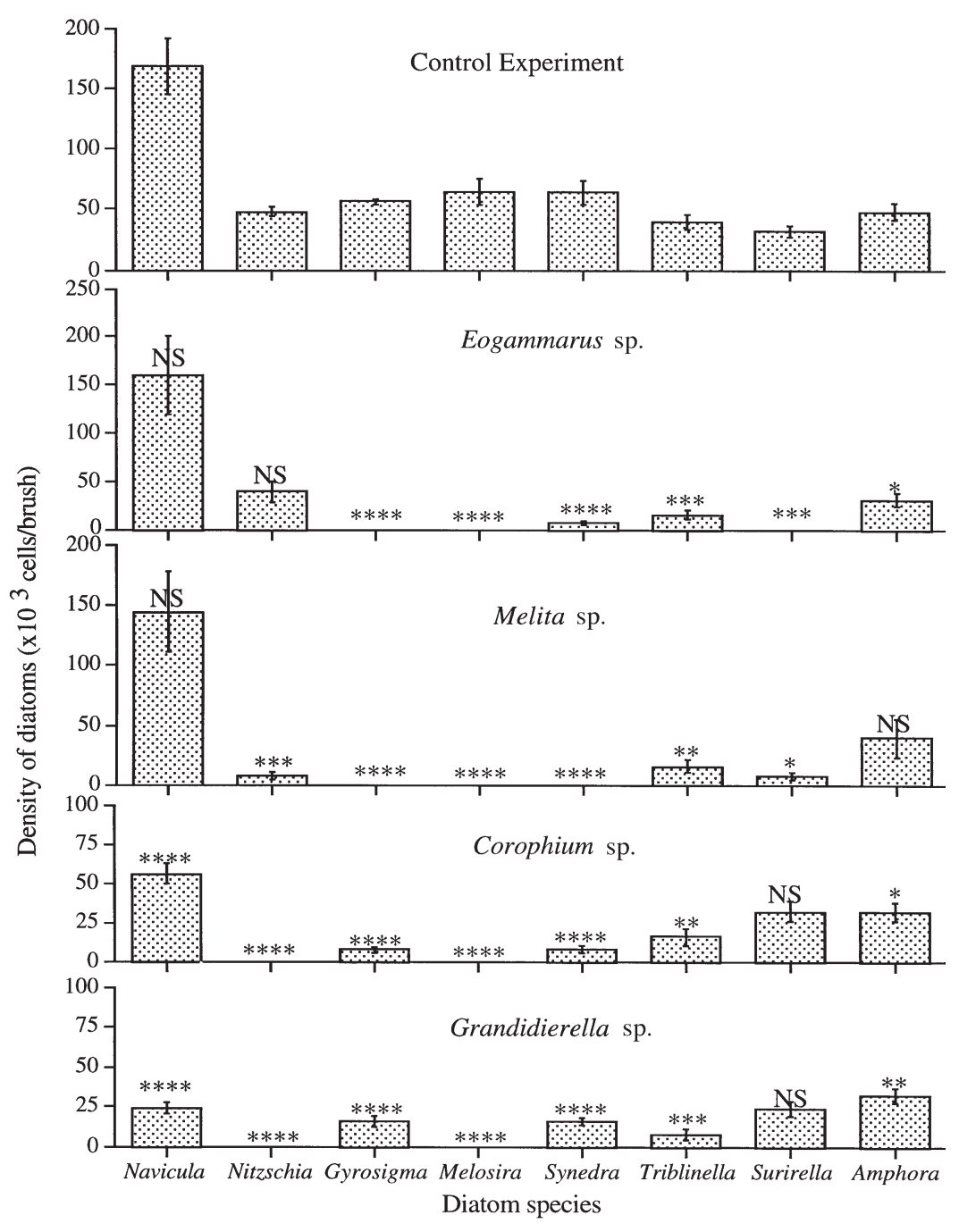

Fig. 9. Density of diatoms on brush substrate used for feeding-pressure experiment in Gamo Lagoon. Bars indicate $\mathrm{SD}, \mathrm{n}=5$. $\mathrm{p}$-values for unpaired $t$-test are shown-****: $\mathrm{p}<0.001 ; * * *: \mathrm{p}<0.005 ; * *: \mathrm{p}<0.01$; $*: \mathrm{p}<0.05$; ns: not significant

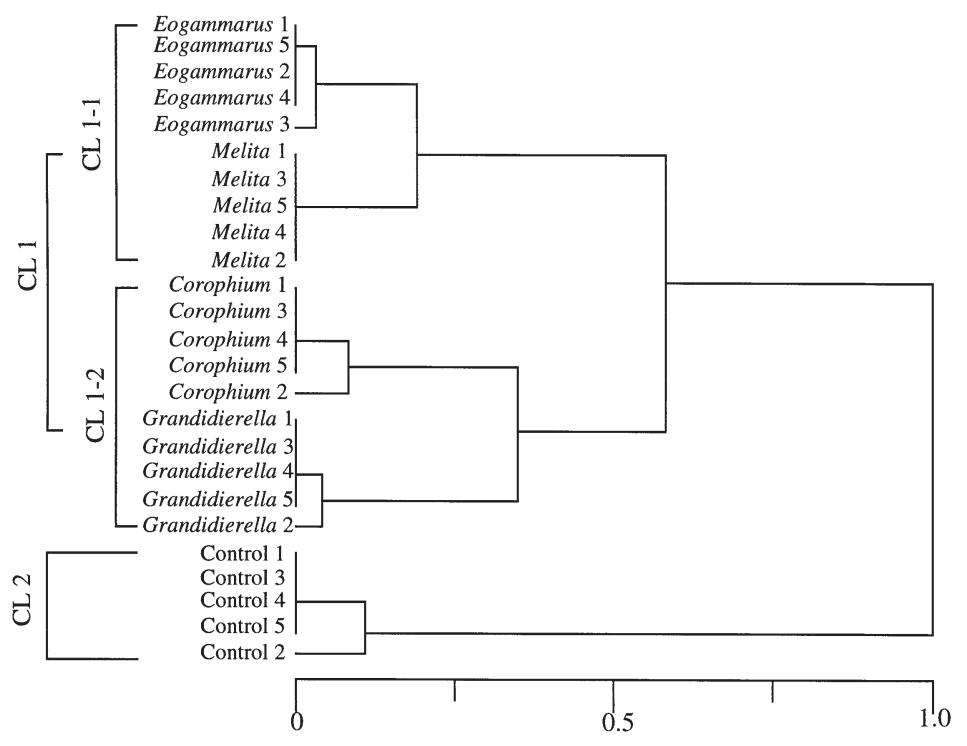

rosigma sp. (Table 3), was significantly (Student's $t$-test, $\mathrm{p}<0.001$ ) ingested by all 4 amphipods in the feeding experiment. Although Gyrosigma sp. is large in size, its slender and elongated form may contribute to its selection. In the feeding pressure experiment, densities of Navicula sp. changed little compared to control tubes, especially for freeliving species. This was also reflected in the field survey of attached material. Although low diatom biomass occurred in the warmer months, Navicula sp. was dominant in most cases (Fig. 8). Kawamura \& Hirano (1992) similarly reported that densities of $N$. britannica tended to be higher from summer to autumn. In the present study comparison of Navicula sp. densities in the tubes of tubedwelling amphipods to densities in the controls revealed that Navicula sp. were ingested significantly (Student's t-test, p < 0.001), suggesting that their dominance in the warmer months may be due to a higher growth rate at that time. The high number of Navicula sp. in the control tubes confirms their higher growth rate. The results of the feeding experiment showed that Amphora sp., an adnate form (attached to the substrate along almost or all of its width), was selected less by the amphipods, and this may be attributable to its strength of adhesion. Kesler (1981) reported that adnate forms such as Cocconeis sp. and Amphora sp. have a low susceptibility to amphipod grazing pressure.

Although diatoms were categorized according to their strength of attachment, grazing pressure exerted was similar for all 3 attachment groups irrespective of adhesion strength (Fig. 8). This suggests that grazing pressure on diatoms in Gamo Lagoon may depend on other factors in addition to their strength of attachment. The results of the feeding experiment revealed that all diatom species were susceptible to feeding pressure from both tube-dwelling and free-living amphipod species, although grazing pressure on different diatom species varied, perhaps in relation to the different lifestyles and cell sizes of the various diatom and amphipod species.

Fig. 10. Diatom assemblages exposed to grazing by each of 4 amphipod species in Gamo Lagoon. Analyses were carried out by single-linkage method based on similarities in their selection of diatom species; 25 tubes were classified into 3 main clusters: Class (CL) 1-1, 1-2 and 2 
Table 3. Diatom species found on Gracilaria vermiculophylla in Gamo Lagoon, showing their life styles and sizes

\begin{tabular}{|lll|}
\hline Diatoms & Life style & \multicolumn{1}{c|}{ Size $(\mu \mathrm{m})$} \\
\hline Navicula sp. & Solitary & Small $(30-40)$ \\
Nitzschia sp. & Solitary & Medium $(65-80)$ \\
Gyrosigma sp. & Solitary & Large $(120-130)$ \\
Melosira sp. & Colonial & Small $(15-25)$ \\
Synedra sp. & Colonial & Medium $(70-85)$ \\
Triblinella sp. & Solitary & Small $(20-30)$ \\
Surirella sp. & Solitary & Medium $(60-90)$ \\
Amphora sp. & Solitary & Small $(20-30)$ \\
Amphiprora sp. & Solitary & Large $(120-150)$ \\
& & \\
\hline
\end{tabular}

Acknowledgements. We are grateful to M. Nishihira and S. Shikano for their advice and contributions to this manuscript. Special thanks to Mrs. L. Aikins for reading the manuscript, and our profound gratitude to the students in the Animal Ecology Laboratory of Tohoku University for their assistance in field sampling.

\section{LITERATURE CITED}

Admiraal W (1977) Influence of light and temperature on the growth rate of estuarine benthic diatoms in culture. Mar Biol 39:1-9

Aikins S, Kikuchi E (2001) Studies on habitat selection by amphipods using artificial substrates within an estuarine environment. Hydrobiologia 457:77-86

Berg CJ Jr (1974) A comparative ethological study of strombid gastropods. Behaviour 51:274-322

Brawley S, Adey W (1981) The effect of micrograzers on algal community structure in a coral microcosm. Mar Biol 61: 167-177

Brock TD (1970) Photosynthesis by algal epiphytes of Utracularia in Everglades National Park. Bull Mar Sci 20: 952-956

Calow P (1973) The food of Ancyclus fluviatilis (Müll), a littoral stone dwelling herbivore. Oecologia 13:113-133

Castenholz RW (1961) The effect of grazing on marine littoral diatom populations. Ecology 42:783-794

D'Antonio C (1985) Epiphytes on the rocky intertidal red alga Rhodomela Larix: negative effects on the host and food for hervibores. J Exp Mar Biol Ecol 86:197-218

Finke LR (1978) Nitrogen fixing (acetylene reduction) by epiphytes on freshwater macrophytes. Appl Environ Microbiol 36:129-135

Hickman M, Round FE (1970) Primary production and standing crops of epipsamic and epipelic algae. Br Phycol J $5: 247-255$

Editorial responsibility: Otto Kinne (Editor),

Oldendorf/Luhe, Germany
Hill MO (1979) TWINSPAN - a FORTRAN program for arranging mulitivariate data in an ordered two-way table by classification of individuals and attributes. Ecology and Systematics, Cornell University, Ithaca, NY

Hudon C (1983) Selection of unicellular algae by the littoral amphipods Gammarus oceanicus and Calliopius laeviusculus (Crustacea). Mar Biol 78:59-67

Jones RC (1980) Productivity of algal epiphytes in a Georgia salt marsh: effect of inundation frequency and implications for total marsh productivity. Estuaries 3:135-317

Jongman RH, ter Braak CJF, van Tongeren OFR (1987) Data analysis in community and landscape ecology. Pudoc, Wageningen

Kawamura T, Hirano R (1992) Seasonal changes in benthic diatom communities colonizing glass slides in Aburatsubo Bay, Japan. Diatom Res 7:227-239

Kesler DH (1981) Periphyton grazing by Amnicola limsa: an enclosure-exclosure experiment. J Freshw Ecol 1:51-59

Kikuchi E, Hanawa K, Kurihara Y (1980) Some problems on the preservation of estuary with special reference to ecology of Gamo Lagoon. Jpn J Limnol 41:117-123 (in Japanese)

Kurihara Y, Kikuchi E, Uehara T, Suzuki T (1997) Report of fundamental investigation of environmental conservation measure for Gamo tidal flat in 1996. Miyagi Prefecture, p 15-16 (in Japanese)

Lorenzen CJ (1967) Determination of chlorophyll and pheopigments: spectrophometric equations. Limnol Oceanogr 12:343-346

Moore JW (1975) The role of algae in the diet of Asellus aquaticus L. and Gammarus pulex L. J Anim Ecol 44:719-730

Morgan MD (1980) Grazing and predation of the grass shrimp Palaemonetes pugio. Limnol Oceanogr 25:896-902

Morrison SJ, White DC (1980) Effects of grazing by estuarine gammaridean amphipods on the microbiota of allochthonous detritus. Appl Environ Microbiol 40:659-671

Nicotri ME (1977) Grazing effects of four marine intertidal herbivores on the microflora. Ecology 58:1020-1032

Randall JE (1964) Contributions to the biology of the queen conch, Strombus gigas. Bull Mar Sci Gulf Caribb 14:246-295

Reyes-Vasquez G (1970) Studies on the diatom flora living on Thalassia testudinum König in Biscayne Bay, Florida. Bull Mar Sci 20:105-134

Steinman AD, Gregory SV, Lamberti GA (1989) Effects of irradiance and grazing on lotic algal assemblages. J Phycol 25:478-485

Sumner WT, Mclntire CD (1982) Grazer-periphyton interactions in laboratory streams. Arch Hydrobiol 93:135-157

Suzuki H, Ioriya T, Seki T, Aruga Y (1987) Changes of algal community on the plastic plates used for rearing the abalone Haliotis discus Hannai. Nippon Suisan Gakkaishi 53:2163-2167

Zimmerman R, Gibson R, Harrington G (1979) Herbivory and detritivory among gammaridean amphipods from a Florida seagrass community. Mar Biol 54:41-47

Submitted: March 12, 2002; Accepted: October 9, 2002

Proofs received from author(s): December 3, 2002 